\title{
COMPARATIVE STUDY OF FASHION AND CONVECTION SMIs IN YOGYAKARTA, SOLO, AND PEKALONGAN
}

\author{
Rina Oktavia, Latri Wihastuti, Anisa Nurpita \\ Universitas Gadjah Mada, Sekolah Vokasi, Departemen Ekonomika dan \\ Bisnis, Yogyakarta 55281, Indonesia
}

\begin{abstract}
Small and Medium Industry (SMI) has an important role in the national economy, especially related to its contribution in employment. SMI is able to create jobs in the informal sector and accommodate workers who are not accommodated in the formal sector. The Ministry of Industry establishes the fashion industry as one of the prioritized industries that will continue to be developed. One of the supporters of the fashion industry is batik which has a high strength of cultural elements so that it can provide high added value. The cities of Yogyakarta, Solo, and Pekalongan are known as the centers of batik in Indonesia. Fashion and convection SMIs especially batik has become a characteristic and livelihood there. However, the performance of the batik industry in Indonesia, including in these three regions, has recently declined. This study aims to conduct a comparative study of fashion and convection SMI in the cities of Yogyakarta, Solo, and Pekalongan. The analytical tool used in this research is descriptive analysis. The results of this study indicate that the three regions have different characteristics.
\end{abstract}

Keywords: fashion and convection SMIs; batik; Yogyakarta City; Solo City; Pekalongan Regency

\section{INTRODUCTION}

Small and Medium Industry (SMI) plays an important role in the national economy, especially related to its contribution in employment. SMI creates employment in the informal sector and is able to accommodate workers who are not accommodated in the formal sector. Informal activities have characteristics

\footnotetext{
*Corresponding Author.

e-mail: e-mail: rina.oktavia@ugm.ac.id
} 
such as small scale, owned by individuals or families, using simple technology, labor intensive, education and expertise of labor are still low, and wages are also relatively low (Bappenas, 2009).

The Ministry of Industry establishes the fashion industry as one of the prioritized industries that will continue to be developed. In 2017, the performance of the fashion industry increased by 8.7 percent and reached USD 13.29 billion. This shows that the national fashion industry has high competitiveness in the international market and has been able to contribute 3.76 percent to the national Gross Domestic Product (GDP). One of the supporters of the fashion industry is batik which has a high strength of cultural elements, thus providings high added value.

Indonesia is a country rich in culture. One of the results of creativity and cultural heritage of the ancestors is batik. Batik is a term used to refer to patterned fabrics used with resist techniques using wax material that has been practiced for thousands of years. Although batik can be found in various countries such as Malaysia, Thailand, India, Sri Lanka, and Iran, Indonesian batik is the most famous batik in the world. The Indonesian batik industry is considered to have been able to dominate the world market and become one of the drivers of the national economy. This can be seen from the achievement of the export value of batik fabric and products in 2017 which had reached USD 58.46 million with the main export destination countries of Japan, the United States, and Europe. According to Gati Wibawaningsih (Republik, 2019), Director General of Small and Medium Industries, the Indonesian batik industry is considered to have comparative and competitive competitiveness in the international market. Indonesia is also considered a market leader who controls the world batik market. The batik industry in Indonesia is dominated by the SMI sector which is spread in 101 centers throughout Indonesia with a total employment of 15,000 people. The potential of the batik industry in Indonesia continues to be developed in line with government efforts to encourage laborintensive export-oriented industries.

The cities of Yogyakarta, Solo, and Pekalongan are known as the centers of batik in Indonesia. The rich city of Yogyakarta has a variety of batik motifs including parang motifs, geometry, banji, vines, aquatic plant motifs, flowers, animals, and others. While Pekalongan is also not inferior to the city of 
Yogyakarta as it has many types of batik, including Chinatown batik, Rifa'iyah batik, Keraton batik, New Java batik, Jlamprang batik, Gedong batik, and so on. Similar to the city of Yogyakarta and Pekalongan, Solo City also has a variety of batik motifs including Kusumo parang batik, modern Solo batik, truntum Solo batik, and so forth. Fashion and convection SMIs, especially those of the batik industry has become a characteristic and livelihood in the three regions.

However, the performance of the batik industry in Indonesia in recent times has faded. This can be seen from the reduction in batik production businesses and the diversion of their businesses to other forms of business. For example, the batik industry in the city of Yogyakarta which originally amounted to 1,200 business units in the early 1970s, currently only 400 business units remain. Data of Batik Cooperatives Association of Indonesian Batik Entrepreneurs (Kobat PPBI) Yogyakarta stated that from 116 business units, only 16 business units are left and only 5 business units actually run their businesses. The same thing happened in the batik industry in Solo, which also experienced a decline as experienced by the batik industry in Yogyakarta. The Pekalongan batik industry also experienced the same thing although it was not as bad as what happened in the batik industry of Yogyakarta City and Solo City. Based on the background above, this study conducted a comparative study of fashion and convection SMIs in the cities of Yogyakarta, Solo, and Pekalongan with the aim to determine the condition of fashion and convection SMIs in the three cities. It is hoped that the obstacles faced by SMIs in fashion and convection in these three cities can be identified, so that policies can be formulated that are appropriate and targeted to the conditions that exist.

\section{LITERATURE REVIEW}

According to Iskandar and Eny Kustiyah (2017), the existence of Indonesian batik is experiencing fluctuations in the search for and in discovery of its cultural identity. The search process takes a long time starting from unexamined cultural identity, cultural identity search, to cultural identity achievement. At present, Indonesian batik is at the stage of cultural identity achievement with the inauguration of batik as an intangible culture of Indonesia by UNESCO. This achievement has been challenged by globalization which carries the school of 
capitalism. Thus, the Indonesian people should take a stand by maintaining the values and beliefs system through batik art which is the characteristic of the Indonesian nation because batik is an identity, an explanation of social strata, cultural language, human spirituality, technological discoveries, and the journey of a civilization that becomes Indonesian national identity.

Meanwhile, according to Setiawati et al. (2015), batik is not only an economic product, but also has a great philosophy in culture, art, and humanism. According to Setiawati et al. (2015), batik entrepreneurs are divided into two groups, namely those who want the maximum profit using the firm's economic type; and household-based batik artisans who use the bazzar economic type.

According to Constitution No. 20 year 2008, regarding Small and Medium Industries (SMIs) or better known as Micro, Small and Medium Enterprises (MSMEs), the distribution of criteria of SMIs/MSMEs is based on the net worth and the sales results of these businesses, which are outlined in the following:

1. Micro Business is a business that has a maximum net worth of $\mathrm{Rp} 50,000,000$, excluding land and buildings for business premises; or have annual sales results of at most $\mathrm{Rp} 300,000,000$.

2. Small Business is a business that has a net worth of more than $\mathrm{Rp} 50,000,000$ up to a maximum of Rp 500,000,000 excluding land and buildings where the business is located; or have annual sales results of more than IDR 300,000,000, up to a maximum of IDR 2,500,000,000.

3. Medium Business is a business that has a net worth of more than $\mathrm{Rp}$ $500,000,000$ up to a maximum of $\mathrm{Rp} 10,000,000,000$ excluding land and buildings where the business is located; or have annual sales results of more than $\mathrm{Rp} 2,500,000,000$, up to a maximum of $\mathrm{Rp} 50,000,000,000$.

Whereas according to BPS, the distribution of SMI criteria is based on the number of workers, namely: (1) home industry with the number of workers of 1-4 people; (2) small industry with the number of workers of 5-19 people; (3) medium industry with a number of workers of 20-99 people; and (4) large industries with more than 100 workers. Despite having different definitions, there are similar characteristics, namely the absence of a clear division of tasks; managed by an individual who is also the owner and manager of the company; and utilizing laborers, family members, and close relatives. 
In the production theory, production is an activity to add value to an item. Production is measured as "the level of output per period of time" because it is a concept of flow. There are 3 aspects of the production process, including:

a) The quantity of goods or services produced

b) The form of goods or services created, and

c) Temporal and spatial distribution of goods or services produced

The production process can be defined as activities that increase the similarity between the pattern of demand for goods or services and the quantity, size, length, and distribution of goods or services available to the market. Production theory states that producer satisfaction is obtained by maximizing the profit of production (maximization of profit).

1. Production process: a series of production activities

2. Distribution process: a series of distribution activities

3. Consumption process: a series of consumption activities

4. Production activities: activities to create/enhance utility

Productivity is carried out by various types of measurements, (BFC, 2005), namely (1) Labor productivity, based on gross output. Measurement of labor productivity used per unit of output, for one or more business units. (2) Labor productivity, based on value-added, measurement of labor productivity used in analysis related to macro and microeconomics, as well as industry's contribution to the economy and economic growth. (3) Capital-labor MFP, based on valueadded, productivity measurements used for analysis related to macro and microeconomics, as well as industry contributions based on multi factor productivity (MFP) on growth, living standards, and structural change analysis. (4) Capital productivity, based on value added. Changes in capital productivity indicate the rate at which output growth can be achieved with lower welfare costs in the form of consumption that has been carried out.

In general, productivity can be interpreted as the relationship between output and input. In addition, it can also be interpreted as a ratio between output to input. Basically, productivity is a measure of the effectiveness and efficiency of a company in obtaining output using available resources. In an effort to ensure the effectiveness of management in the company's business processes, it is important for SMIs to establish and implement appropriate productivity mea- 
surement systems that can provide information on how effective and efficient the company is in managing available resources. Productivity measurement is a communication tool that provides information related to the company's current performance achievements and compares it with the company's stated goals and standards (Wong, 2015).

Basically, productivity measurement is a process to identify the exact calculation or metric that will be used to determine the effectiveness and efficiency of the resources used (Wong, 2015). Furthermore, the productivity measurement system helps SMIs to find out whether the efforts to increase productivity implemented are going well or not (Wong, 2015).

\section{RESEARCH METHODOLOGY}

The data used in this study are primary data and secondary data. Primary data is data obtained directly from the object of research conducted by researchers both individually and in groups. The primary data is obtained from the field study results. Field study is carried out by going to the field to get information, data, and conditions of SMIs in fashion and convection in Yogyakarta, Pekalongan, and Solo. Data collection was carried out using a questionnaire and direct interview forms.

Secondary data is obtained from a data source or from an institution where the data is not obtained directly from the objects of research. The secondary data is obtained from the desk study. Desk study is done by compiling, reviewing, and analyzing using secondary data and primary data obtained from the field. This secondary data was obtained from the statistical body of Yogyakarta City, Pekalongan Regency, and Solo City.

The population in this study are all fashion and convection SMIs in Yogyakarta, Pekalongan and Solo. This research is done in three locations. According to Gay and Diel (1992), for comparative studies, the minimum number of samples per group was 30 fashion and convection SMIs. Based on these provisions, the following are the details and number of samples in the study:

1. Yogyakarta City 43 SMIs in fashion and convection

2. Pekalongan Regency 45 SMIs in fashion and convection 
3. Solo City 30 SMIs in fashion and convection

The sampling technique is done by purposive sampling. Purposive sampling is a non-random sampling technique where the researcher determines sampling by determining specific characteristics that are appropriate to the purpose of the study so that it can be expected to answer the research problem.

The analytical tool used is descriptive statistical analysis. Data analysis is one of the research processes conducted after all the data needed to solve the problem under study has been obtained completely. The appropriateness and accuracy in the use of analytical tools determine the accuracy of the conclusion, therefore the data analysis activity is an activity that cannot be ignored in the research process. The analysis technique is divided into two parts, namely quantitative analysis techniques and qualitative analysis techniques.

Presentation of data in descriptive statistics include presentation of data through tables, graphs, diagrams (bars, circles and scatter) circles, polygons, histograms, calculation of mean, median, mode, percentile, quartile, decile, calculation of data distribution, and through calculation of average and standard deviation, as well as calculation of percentages.

\section{DISCUSSION}

\subsection{Business Profile of Fashion and Convection SMIs in Yogyakarta, Solo, and Pekalongan City}

Knowing the business profile of small and medium industries (SMI) is an important and fundamental thing in order to recognize these SMIs in more detail. The intended business profile includes business forms, the number of workers, and the sales turnover of fashion and convection SMIs in the cities of Yogyakarta, Solo, and Pekalongan.

\subsubsection{Business Forms of Fashion and Convection SMIs in Yogyakarta, Solo, and Pekalongan}

The form of business of batik Small and Medium Industry (SMI) of an area, in this case the City of Yogyakarta, Solo, and Pekalongan, among others are in 
the form of an individual business/non-business entity, a limited partnership/ commanditaire vennootschap company (CV), a Limited Liability Company (PT), or cooperative. The fashion business of fashion and convection SMIs in Yogyakarta City is dominated by individual businesses/non-business entities by 91 percent or 39 business units. The remainder, which is 7 percent or 3 business units are in the form of a limited partnership/commanditaire vennootschap (CV), and the other 2 percent or 1 business unit is in the form of a cooperative. The fashion business of fashion and convection SMIs in the city of Solo is dominated by individual businesses/non-business entities of 90 percent or 27 business units. The rest, which is 10 percent or 3 business units are in the form of a limited partnership company/commanditaire vennootschap (CV). The fashion business of fashion and convection SMIs in Pekalongan Regency is dominated by individual businesses/non-business entities of 98 percent or 44 business units. The rest, which is 2 percent or 1 business unit is in the form of a limited partnership/ commanditaire vennootschap (CV).

The business forms of SMIs in fashion and convection in the cities of Yogyakarta, Solo, and Pekalongan Regency are mostly privately owned with various brands provided. If a comparison of the Fashion and convection SMI business forms between the cities of Yogyakarta, Solo, and Pekalongan is obtained, there will be a similarity between the three, namely the business forms in how the three regions are dominated by individual business forms, which reach 90 percent of the total business units. The high level of individual/NonBusiness Entity in fashion and convection SMIs is caused by the level of sales and production that are still considered not too large so that fashion and convection SMIs do not need to form a PT, CV, UD or cooperative. In addition, individual business forms are easier to manage than other forms of business.

\subsubsection{Workforce of Fashion and Convection SMIs in Yogyakarta, Solo, and Pekalongan City}

Regarding the number of fashion and convection workers in Yogyakarta City, 47 percent or 20 business units that has a workforce of around 1-4 workers. Meanwhile, 37 percent or 16 business units have a workforce of around 5-19 people. 9 percent or 4 business units do not have labor (total labor $=0$ ), 
and 7 percent or 3 other business units have workforce ranging from 20-99 workers. Thus, it can be concluded that the majority of fashion and convection SMIs in Yogyakarta City are in the type of micro industry because they only consist of 1-4 workers. Furthermore, the second largest type of fashion and convection SMI in the city of Yogyakarta is small industry consisting of 5-19 workers. Only a small portion, which is equal to 7 percent of fashion and convection SMIs in Yogyakarta is of the medium industry type. However, in Yogyakarta there are still 9 percent of fashion and convection SMIs that do not have manpower or in other words are still done by business owners themselves.

Regarding the number of fashion and convection workers in Solo City, 44 percent or 13 business units has a workforce of around 1-4 workers. Meanwhile, 33 percent or 10 business units have a workforce of 6-19 people. While the remaining 23 percent or 7 business units have a workforce of more than 20 people. Thus, it can be concluded that the majority of fashion and convection SMIs in Solo are micro industry because they only have 1-4 workers. The second largest type of fashion and convection SMIs in Solo is a small industry with a workforce of 6-9 people. While the rest, is a type of medium industry that has a workforce of more than 20 people. To note, in the city of Solo the types of Fashion and convection SMIs are quite diverse, both micro, small, and medium industries.

Regarding the number of fashion and convection SMIs in Pekalongan Regency, 42 percent or 19 business units have 6-19 workers. Meanwhile, 33 percent or 15 business units have a workforce of 20-99 people. As much as 20 percent or 9 business units have 1-4 workforce, and the remaining 5 percent or 2 business units have more than 100 workforce. Thus, it can be concluded that the majority of fashion and convection SMIs in Pekalongan Regency are a type of small industry because they have a workforce of 6-19 people. The second largest type of fashion and convection SMIs in Pekalongan Regency is medium industry with a workforce of 20-99 people. In addition, there are also three types of micro industries in the sequence and types of large industries that only makes up for 2 percent of the total. To note, in the Pekalongan Regency the types of fashion and convection SMIs are dominated by small and medium industries, and there are also large industries that have more than 100 workers. Most fashion and convection SMIs in Pekalongan Regency indeed have a large scale of production so that it requires a considerable amount of labor. 
If a comparison is made relating to the number of fashion and convection SMIs in the three regions, it can be seen that the three regions have different types of industry characteristics. Fashion and convection SMIs in Yogyakarta City tend to be micro and small industries. This is similar to Fashion and convection SMIs in the city of Solo, which is also dominated by micro and small industries. However, for fashion SMIs and Yogyakarta City convection there are still those whose owners do their own business. This character is only owned by fashion and convection SMIs in Yogyakarta City. In addition, in the city of Solo the number of fashion and convection SMIs that are of the medium industry type is still greater than that of Yogyakarta City. The character of the types of Fashion and convection SMIs in Pekalongan Regency is different from the other two regions. In Pekalongan Regency, it is dominated by small and medium industries. In fact, in Pekalongan Regency there is a large batik industry which reaches 5 percent of the total. This is because the scale of production in Pekalongan Regency is quite large when compared to the other two regions.

\subsubsection{Turnover of Fashion and convection SMIs Sales in Yogyakarta, Solo, and Pekalongan}

Regarding fashion and convection SMIs in the city of Yogyakarta, 42 percent or 18 business units have sales turnover below Rp 10,000,000/month. Meanwhile, 37 percent or 16 other business units have a sales turnover of $\mathrm{Rp}$ $11,000,000-50,000,000 /$ month. The remaining 12 percent or 5 business units have a turnover of Rp 51,000,000-100,000,000/month, and 9 percent or 4 other business units have turnover above $\mathrm{Rp} 100,000,000 /$ month. Thus, it can be concluded that the majority of fashion and convection SMIs in the majority of Yogyakarta City have a turnover of under Rp 10,000,000/month.

Regarding fashion and convection SMI sales in Solo City, 56 percent or 17 business units have sales turnover below Rp 10,000,000 per month. While 30 percent or 9 Fashion and convection SMIs in the city of Solo has a sales turnover of Rp 11,000,000-50,000,000/month. While 7 percent or 2 fashion and convection SMIs have a sales turnover of Rp 51,000,000-100,000,000/month, and the remaining 7 percent or 2 other fashion and convection SMIs have sales turnover above $\mathrm{Rp} \mathrm{100,000,000/month.} \mathrm{Thus,} \mathrm{it} \mathrm{can} \mathrm{be} \mathrm{concluded} \mathrm{that} \mathrm{the} \mathrm{fashion} \mathrm{and}$ 
convection SMIs in Solo have a small scale of production when viewed from monthly sales turnover.

The sales turnover of Fashion and convection SMIs in Pekalongan Regency mostly are above Rp 100,000,000/month. The number of fashion and convection SMIs with a large sales turnover reached 58 percent or 26 fashion and convection SMIs. While 20 percent or 9 fashion and convection SMIs in Pekalongan Regency have a turnover of under Rp 10,000,000/month. The remaining 11 percent or 5 fashion and convection SMIs in Pekalongan Regency have a turnover of Rp 11,000,000-50,000,000/month and 11 percent or 5 other fashion and convection SMIs have a sales turnover of Rp 51,000,000-100,000,000/month. Thus, it can be concluded that the fashion and convection SMIs have a large scale of production when viewed from the size of the sales turnover received.

If a comparison is made of the sales turnover of fashion and convection SMIs in Yogyakarta, Solo, and Pekalongan, then it can be seen that there are similarities between fashion and convection SMIs of Yogyakarta and Solo city in which the majority of sales turnover is under Rp 10,000,000/month. The second position was held by Fashion and convection SMIs with a sales turnover of Rp 11,000,000-50,000,000/month. Followed by Fashion and convection SMIs with sales turnover of Rp 51,000,000-100,000,000/month and sales turnover above $\mathrm{Rp}$ 100,000,000/month which occupies the last position. Unlike the fashion and convection SMIs in the cities of Yogyakarta and Solo, the fashion and convection SMIs in Pekalongan Regency are actually dominated by industries that have a sales turnover of more than Rp 100,000,000/month. This shows that Fashion and convection SMIs in Pekalongan Regency has a very large scale of production seen from the high sales turnover per month.

\subsection{Production Factors of Fashion and Convection SMIs in the Cities of Yogyakarta, Solo, and Pekalongan}

The condition of production factors of fashion and convection SMIs in Yogyakarta, Solo, and Pekalongan include the origin of raw materials in the production process, sources of labor, sources of capital, knowledge of production processes, origin of technology, and business locations of the fashion and convection SMIs. 


\subsubsection{The origin of raw materials for Fashion and Convection SMIs in Yogya- karta, Solo, and Pekalongan}

The origin of raw materials in the production process of fashion and convection SMIs in the City of Yogyakarta amounted to 63 percent from within the city, while the rest, which is 37 percent from outside the city of Yogyakarta. Regions which are the suppliers of fashion and convection SMIs in Yogyakarta include: Yogyakarta, Bandung, Jakarta, Solo, Tangerang, Surabaya, Jepara, and Pekalongan. The origin of raw materials in the production process of fashion and convection SMIs in the City of Solo by 70 percent comes from the city, while the remaining 30 percent comes from outside the city of Solo. The regions that become suppliers of raw materials for the production of fashion and convection SMIs include: Solo, Bandung, Jakarta, and Pekalongan. The origin of raw materials in the production process of fashion and convection SMIs in Pekalongan Regency by 54 percent came from the city, while the remaining 46 percent came from outside the City of Pekalongan. Regions that are suppliers of raw materials for the SMIs include: Pekalongan, Bandung, Jakarta, Solo, and Tangerang.

If a comparison is made regarding the origin of raw materials in the production process of fashion and convection SMIs in the cities of Yogyakarta, Solo, and Pekalongan, it will be known that the raw materials in the production process of the three regions are equally dominated from within the city. However, Solo City is ranked first that utilizes raw materials from within the city, followed by Yogyakarta City, and Pekalongan Regency. Some regions that are often suppliers of raw materials include Solo, Pekalongan, Bandung, and Jakarta.

Table 1 The origin of Fashion and convection SMIs in Yogyakarta, Solo, and Pekalongan

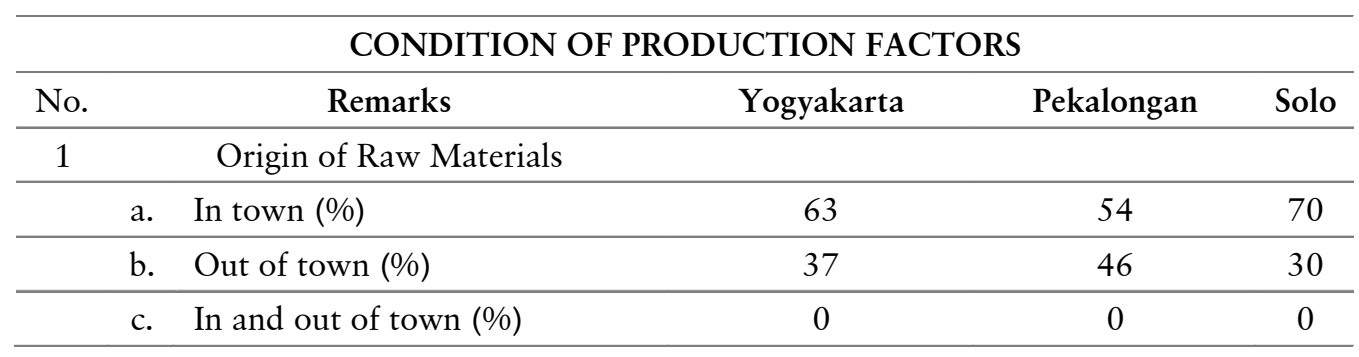

Source: Data Processed, 2019 


\subsubsection{The origin of Fashion and Convection SMI Workerforce in Yogyakarta, Solo, and Pekalongan}

Regarding the origin of the Yogyakarta Fashion and convection SMIs workforce, 86 percent of the workforce at the Fashion and convection SMIs came from within the city, while the remaining 7 percent each came from inside and outside the city of Yogyakarta. Regions which are the source of fashion and convection SMIs workforce include: Yogyakarta, Jember, Solo, and Bandung. The origin of the fashion and convection SMIs in the Solo is 70 percent of the workforce come from within the city, while the remaining 30 percent come from inside and outside the city of Solo. Regions which are the source of the workforce include: Solo, Pekalongan, and Yogyakarta. The origin of the fashion and convection SMIs workforce in Pekalongan Regency is 98 percent from within the city, while the remaining 2 percent come from outside the City of Pekalongan. Regions which are the source of fashion and convection SMIs workforce include: Pekalongan and Batam.

If a comparison is made regarding the origin of the fashion and convection SMIs in Yogyakarta, Solo, and Pekalongan, it can be concluded that the three regions together have the majority of workers coming from within the city. The large percentage of the workforce in fashion and convection SMIs from within the three regions reaches more than 70 percent of the total workforce. This is because the use of labor from within the city will minimize costs, and this will become easier and more practical management for fashion and convection SMIs.

Table 2 The Origin of Fashion and Convection Workerforce in Yogyakarta, Solo, and Pekalongan City

\section{CONDITION OF PRODUCTION FACTORS}

\begin{tabular}{|c|c|c|c|c|}
\hline No. & Remarks & Yogyakarta & Pekalongan & Solo \\
\hline 2 & Origin of Workforce & & & \\
\hline & a. In town $(\%)$ & 86 & 98 & 70 \\
\hline & b. Out of town (\%) & 7 & 2 & 30 \\
\hline & c. In and out of town (\%) & 7 & 0 & 0 \\
\hline
\end{tabular}

Source: Data Processed, 2019 
4.2.3 Source of Capital for Fashion and Convection SMIs in the City of Yogyakarta, Solo, and Pekalongan

Regarding sources of capital for fashion and convection SMIs in Yogyakarta City, 84 percent of capital sources in fashion and convection in Yogyakarta City came from their own capital, while the remaining 9 percent each came from loans and combination between own capital and loans at 7 percent. Thus, it can be concluded that the source of capital from one's own funding is still the main focus of SMIs in fashion and convection in the city of Yogyakarta. Sources of capital in fashion and convection SMIs in Solo City is 73 percent from owner's equity, while the remaining 27 percent comes from loans. Thus, it can be concluded that the source of capital from own capital is still the main focus of SMIs in fashion and convection in the city of Solo. The source of capital in Pekalongan Regency fashion and convection is 96 percent from owner's equity, while the remaining 4 percent comes from loans. Thus, it can be concluded that the source of capital from own capital is still the main focus of SMIs in fashion and convection in Pekalongan Regency.

If a comparison is made of the sources of capital for fashion and convection SMIs in the cities of Yogyakarta, Solo, and Pekalongan, it can be seen that all three cities relies on their own capital as the foundation to run the fashion and convection SMI business activities. The portion of funding sources from loans in the capital structure of Fashion and convection SMIs is very small. From the information gathered from the respondents, it is known that the amount of capital needed for SMIs in fashion and convection is quite large, so relying on loaned capital will be difficult for the owners of SMIs in fashion and convection. In addition, there are fears of default on the owners of Fashion and convection SMIs due to the high level of risk.

Table 3 Source of Capital for Fashion and Convection SMIs in the City of Yogyakarta, Solo, and Pekalongan

\begin{tabular}{|c|c|c|c|c|c|}
\hline \multicolumn{6}{|c|}{ CONDITION OF PRODUCTION FACTORS } \\
\hline No. & & Remarks & Yogyakarta & Pekalongan & Solo \\
\hline \multirow[t]{4}{*}{3} & & Source of Capital & & & \\
\hline & a. & Owner's equity (\%) & 84 & 96 & 73 \\
\hline & b. & Loans from Financial Institution (\%) & 9 & 4 & 27 \\
\hline & c. & Owner's equity and Loans (\%) & 7 & 0 & 0 \\
\hline
\end{tabular}

Source: Data Processed, 2019 


\subsubsection{The Origin of Production Processes Knowledge for Fashion and Convec- tion SMIs in the City of Yogyakarta, Solo, and Pekalongan}

The origin of knowledge of the production process of fashion and convection SMIs in Yogyakarta City is 65 percent from independent learning processes (self-taught), while the remaining 21 percent came from the learning process at school, and 14 percent came from ancestral heritage. Thus, it can be concluded that the majority of knowledge about the production process of fashion and convection SMIs in the city of Yogyakarta comes from the self-taught learning process.

The origin of knowledge about the production process of fashion and convection SMIs in Solo City is 63 percent from ancestral heritage, while 33 percent came from the learning process at school, and the remaining 27 percent came from independent learning process (self-taught). Thus, it can be concluded that the majority of knowledge about the production process of fashion and convection SMIs in the city of Solo originated from ancestral heritage.

The origin of knowledge of the production process of fashion and convection SMIs in Pekalongan Regency is 62 percent from self-taught processes, while the remaining 33 percent came from ancestral heritage, and the other 5 percent came from from the learning process at school. Thus, it can be concluded that the majority of knowledge about the production process of fashion and convection SMIs in Pekalongan Regency comes from self-taught learning processes.

If a comparison is made regarding the origin of the knowledge of the production process of fashion SMIs and the convection of Yogyakarta, Solo, and Pekalongan, the similarities between the City of Yogyakarta and Pekalongan Regency is that the knowledge is dominated by self-taught learning processes as the origin of the knowledge of the fashion and convection SMIs production process. Unlike the city of Solo which is dominated by heritage (ancestors) as the origin of knowledge of the production process of fashion and convection SMIs. Thus, Fashion and convection SMIs in Yogyakarta City and Pekalongan Regency is the result of an independent search by each business owner. Meanwhile, Fashion and convection SMIs in the city of Solo is a legacy passed down from the previous owners to his descendants. 
Table 4 The Origin of Production Processes Knowledge for Fashion and Convection SMIs in the City of Yogyakarta, Solo, and Pekalongan

\begin{tabular}{ccccc}
\hline \multicolumn{5}{c}{ CONDITION OF PRODUCTION FACTORS } \\
\hline No. & \multicolumn{1}{c}{ Remarks } & Yogyakarta & Pekalongan & Solo \\
\hline 4 & Knowledge of Production Process & & & \\
\hline \multicolumn{2}{c}{ a. Self-Taught (\%) } & 65 & 62 & 27 \\
\hline & b. Ancestral heritage (\%) & 14 & 33 & 63 \\
\hline & c. Formal Education (\%) & 21 & 5 & 10 \\
\hline
\end{tabular}

Source: Data Processed, 2019

\subsubsection{Origin of Technology (Production Machines) of Fashion and Convection SMIs in Yogyakarta, Solo, and Pekalongan City}

Regarding fashion and convection SMI technology in Yogyakarta City, as much as 95 percent comes from owner's own purchases, while the remaining 5 percent comes from collaboration between owner's own purchases and government and private endowments. Thus, it can be concluded that the fulfillment of technological needs is still mainly fulfilled by the owner himself. The endowment provided by the government for Fashion and convection SMIs in the city of Yogyakarta is still very small. Fashion and convection SMIs technology in Solo as a whole (100 percent) comes from the owner's own purchase. Thus, it can be concluded that the fulfillment of the needs of fashion and convection SMI technology in Solo City is fulfilled by the owner independently without any assistance from the local government. Fashion and convection SMI technology in Pekalongan Regency is 91 percent from owners' own purchases, while the remaining 9 percent came from government and private assistance. Thus, it can be concluded that the fulfillment of technology needs is still mainly met by the owner himself. The assistance provided by the government for SMIs in fashion and convection in Pekalongan Regency is still very small.

If a comparison is made between the technology of fashion and convection SMIs of Yogyakarta, Solo, and Pekalongan, a similarity will be found between the three, which is equally meeting the technological needs by the owner's own purchases. The assistance provided by both the government and the private sector is very small, even none in the city of Solo. This shows that the level of 
support and participation of external parties in efforts to develop SMIs in fashion and convection is very small.

Table 5 The origin of Technology for Fashion and Convection SMIs in the Cities of Yogyakarta, Solo, and Pekalongan

\begin{tabular}{|c|c|c|c|c|}
\hline \multicolumn{5}{|c|}{ CONDITION OF PRODUCTION FACTORS } \\
\hline No. & Remarks & Yogyakarta & Pekalongan & Solo \\
\hline 5 & Origins of Technology Used & & & \\
\hline & a. Purchased (\%) & 95 & 91 & 100 \\
\hline & b. Endowment (\%) & 0 & 9 & 0 \\
\hline & c. Purchased and Endowment (\%) & 5 & 0 & 0 \\
\hline
\end{tabular}

Source: Data Processed, 2019

\subsubsection{Business Location of Fashion and Convection SMIs in Yogyakarta, Solo, and Pekalongan City}

The location of fashion and convection SMIs in the city of Yogyakarta is 70 percent in the city, while the remaining 30 percent is in the suburban area. This is because the center of Yogyakarta's Fashion and convection SMI activities is in the city. The location of Fashion and convection SMIs in Solo City as a whole (100 percent) is in the city. This is because the center of the Fashion and convection SMIs activities in the city of Solo is in the city. The location of fashion and convection SMIs in Pekalongan Regency as a whole (100 percent) comes from the suburban area. This is because the center of Fashion and convection SMI activities in Pekalongan Regency is on the suburban area.

If a comparison is made regarding the business locations of fashion and convection SMIs in the cities of Yogyakarta, Solo, and Pekalongan, it can be seen that the similarity between the cities of Yogyakarta and Solo is the dominant business locations in the city. While difference can be seen in Pekalongan Regency which has a dominant business location on the outskirts of the city. This condition occurs because the location of the business is placed close to the factors of production so that later it will be able to minimize costs. Although in the end marketing activities will not only be around the business location, but spread out to various areas outside the city. 
Table 6 Business Location of Fashion and Convection SMIs in Yogyakarta, Solo, and Pekalongan City

\begin{tabular}{|c|c|c|c|c|}
\hline \multicolumn{5}{|c|}{ CONDITION OF PRODUCTION FACTORS } \\
\hline No. & Remarks & Yogyakarta & Pekalongan & Solo \\
\hline 6 & Business Location & & & \\
\hline & a. In the city $(\%)$ & 70 & 0 & 100 \\
\hline & b. Suburban area $(\%)$ & 30 & 100 & 0 \\
\hline
\end{tabular}

Source: Data Processed, 2019

4.3 Condition of Fashion and convection SMIs Products in Yogyakarta, Solo, and Pekalongan City

The condition of fashion and convection SMI products from the cities of Yogyakarta, Solo, and Pekalongan, including product types, product pricing strategies, product distribution, promotion strategies, and government support for SMI industry and convection fashion.

\subsubsection{Types of Fashion and convection SMIs Products in Yogyakarta, Solo, and Pekalongan City}

The characteristics of the types of fashion and convection SMI products in Yogyakarta City are mostly dominated by the many variants of products which reach 74 percent. Meanwhile, the other 21 percent are standard products. However, 9 percent of some types of fashion and convection SMI products in Yogyakarta began to be discontinued due to lack of demand in the market. Only 2 percent of Yogyakarta's Fashion and convection SMI products have several brands for one product line. Thus, it can be concluded that the types of fashion and convection SMIs in Yogyakarta City have high product variant characteristics that can be a superior product type. This indicates the high level of creativity of fashion and convection SMIs in the city of Yogyakarta. Unfortunately, there are several (although relatively small in number) types of fashion and convection SMI products that do not have many variants so that some of these products may be discontinued due to low market demand. 
The characteristics of the types of fashion and convection SMIs products in Solo City are mostly standard products which account for 60 percent. Meanwhile, the remaining 33 percent are products with high variants, and the other 7 percent are fashion and convection SMIs products that have begun to be discontinued due to lack of demand in the market. Thus, it can be concluded that the types of products produced by fashion and convection SMIs in Solo City are mostly standard products according to market demand in general. This is because the standard product can meet the capacity and market demand so that it is considered sufficient for business continuity. However, a number of fashion and convection SMIs produce many product variants. Although there are still a number of fashion and convection SMIs which have been discontinued due to a lack of market demand. This indicates the level of market saturation of the products produced by SMIs in fashion and convection in the city of Solo.

The characteristics of the types of fashion and convection SMI products in Pekalongan Regency are mostly dominated by the many product variants that reach 53 percent. Meanwhile, 45 percent of products produced by fashion and convection SMIs are standard products. The remaining 2 percent are fashion and convection SMIs which have several brands for one product line at 2 percent. Thus, it can be concluded that the characteristics of fashion and convection SMI products from Pekalongan Regency have several market segments. The first is SMIs which offer a variety of products with a high level of creativity, and the second is limited to meeting the demand for standard products in the market.

If a comparison is made of the types of products of fashion SMIs and convection of Yogyakarta, Solo, and Pekalongan, a similarity will be found between Yogyakarta City and Pekalongan Regency which have varied types of products. This is different from the fashion and convection SMIs from the city of Solo whose types of products are standard products in accordance with market demand. This indicates that Fashion and convection SMIs of Yogyakarta City and Pekalongan Regency have a high level of creativity because they have succeeded in producing varied products. 
Table 7 Types of Fashion and convection SMIs Products in Yogyakarta, Solo, and Pekalongan City

\begin{tabular}{|c|c|c|c|c|}
\hline \multicolumn{5}{|c|}{ PRODUCT CONDITION } \\
\hline No. & Remarks & Yogyakarta & Pekalongan & Solo \\
\hline \multirow[t]{5}{*}{1} & Products Produced & & & \\
\hline & a. Only standard products (\%) & 15 & 45 & 60 \\
\hline & b. A variety of products (\%) & 74 & 53 & 33 \\
\hline & $\begin{array}{l}\text { c. Several brands for a product } \\
\text { line }(\%)\end{array}$ & 2 & 2 & 0 \\
\hline & $\begin{array}{l}\text { d. Production of some variants is } \\
\text { discontinued due to lack of } \\
\text { demand }(\%)\end{array}$ & 9 & 0 & 7 \\
\hline
\end{tabular}

Source: Data Processed, 2019

\subsubsection{Price Strategy for Fashion and Convection SMIs in Yogyakarta, Solo, and Pekalongan City}

Regarding Yogyakarta Fashion and Convection SMIs, 63 percent used a price strategy by setting production costs plus margins. While 22 percent use the pricing strategy by making adjustments to competitor prices. While the remaining 9 percent uses a strategy in determining prices by as much as possible minimize costs and the other 6 percent use a strategy with price penetration. Thus, it can be concluded that most of the fashion and convection SMIs of Yogyakarta City in competing in the market are enough to use a strategy of setting production costs plus margins.

Regarding Solo City fashion and convection SMIs, 67 percent use a product pricing strategy by setting production costs plus margins. While the remaining 20 percent sets their price by adjusting to competitor prices and another 7 percent by setting penetrating prices. Thus, it can be concluded that most of the fashion and convection SMIs of Solo are simply using a strategy of setting production costs plus margins to compete in the market.

Regarding fashion and convection SMIs in Pekalongan Regency, 44 percent use the price strategy by setting production costs plus margins. While the remaining 39 percent by adjusting prices to competitors' prices and setting penetration prices by 2 percent. Thus, it can be concluded that there are 2 main 
price strategies used by SMIs in fashion and convection in Pekalongan Regency, namely by setting production costs plus margins and making price adjustments to competitor prices.

If a price strategy is compared between the cities of Yogyakarta, Solo, and Pekalongan, it can be concluded that the main strategy of the prices of the three is almost the same, namely the price compiled from production costs plus margins. While the second strategy is pricing determined by adjusting to competitor prices. However, the percentage of each pricing strategy in three different regions is different. The cities of Yogyakarta and Solo have almost the same percentage, while Pekalongan Regency is slightly different. It can be said that the proportion between pricing strategies by determining production costs plus margins and strategies to adjust prices with competitor prices are almost the same. Thus, it can be concluded that the fashion and convection SMIs in Pekalongan Regency can be a tough competitor for brands with competitive price levels.

Table 8 Price Strategy for Fashion and Convection SMIs in Yogyakarta, Solo, and Pekalongan City

\begin{tabular}{|c|c|c|c|c|}
\hline \multicolumn{5}{|c|}{ PRODUCT CONDITION } \\
\hline No. & Remarks & Yogyakarta & Pekalongan & Solo \\
\hline \multirow{5}{*}{2} & Price Strategy & & & \\
\hline & a. Production cost and margin (\%) & 63 & 44 & 67 \\
\hline & b. Penetration price $(\%)$ & 6 & 17 & 13 \\
\hline & c. Adjusted to competitors' pricing (\%) & 22 & 9 & 20 \\
\hline & $\begin{array}{l}\text { d. Maximizing cost efficiency to lower } \\
\text { prices }(\%)\end{array}$ & 9 & 0 & 0 \\
\hline
\end{tabular}

Source: Data Processed, 2019

\subsubsection{Distribution/Marketing of Fashion and convection SMIs Products in Yogyakarta, Solo, and Pekalongan City}

The distribution of Yogyakarta Fashion and convection SMI products is 40 percent through orders, 26 percent through on-site sales, 14 percent through sales to retailers, 10 percent through exports, and the remaining 10 percent through sales to big traders in the city of Yogyakarta. Thus, it can be concluded 
that in distributing products, SMIs in fashion and convection in Yogyakarta City serve more orders and sales in place compared to other distribution channels. This indicates that Yogyakarta fashion and convection SMI is still in a small scope, which is limited to serving orders and sales on the spot.

The distribution of fashion and convection products in Solo City is 44 percent through selling off to large traders, 23 percent through sales on the spot, 7 percent through exports, 13 percent through orders, and the remaining 13 percent through selling off to retailers in the city of Solo. Thus, it can be concluded that the distribution of the production of fashion SMIs and Solo City convection serves more sales to large traders and on-site sales. This indicates that fashion and convection SMIs in Solo City acts as a supplier for other large traders besides selling products on the spot. In other words, the Fashion and convection SMIs of Solo City is widely distributed because it serves large traders from various regions.

The distribution of Fashion and convection SMIs products in Pekalongan Regency is 57 percent through selling off to large traders, 15 percent through consignment to retailers, 13 percent through orders, 11 percent through selling off to retailers, and the remaining 4 percent through on-site sales. Thus, it can be concluded that the distribution of the products of fashion SMIs and convection of Pekalongan Regency is more in the form of sales to large traders. In other words, the Fashion and convection SMIs of Pekalongan Regency has a wide distribution channel because it serves large traders from various regions.

If we compare the distribution of fashion and convection products of Yogyakarta, Solo, and Pekalongan, it will be seen that Yogyakarta City relies more on the distribution of its products from orders and sales on-site. Whereas Pekalongan Regency and Solo City rely more on the distribution of their products through sales to large traders. This is because the scale of production in Yogyakarta City is smaller compared to the other two regions. Yogyakarta City fashion and convection SMIs will produce when they get an order or limited sales on the spot. Thus, orders are the main basis of the production activities of fashion SMIs and Yogyakarta City convection. It is different from Solo City and Pekalongan Regency which produce and distribute their products to large traders.

The marketing scope of the Yogyakarta Fashion and convection SMIs products is 57 percent out of town, 32 percent inside the city, 9 percent 
nationally, and 2 percent abroad. The marketing scope of Pekalongan Regency's Fashion and convection SMIs products is 87 percent outside the city, 9 percent inside the city, 2 percent nationally and 2 percent abroad. The scope of marketing of fashion and convection products in Solo City is 72 percent outside the city, 16 percent inside the city, 6 percent nationally and 6 percent abroad.

If a comparison is made of the marketing scope of the products of fashion and convection SMIs in Yogyakarta, Solo, and Pekalongan, it will be seen that the three regions equally market most of their products outside the city. It's just that the city of Yogyakarta is also quite large in marketing its products in the city.

Table 9 Distribution/Marketing of Fashion and convection SMIs Products in Yogyakarta, Solo, and Pekalongan City

\begin{tabular}{|c|c|c|c|c|}
\hline \multicolumn{5}{|c|}{ PRODUCT CONDITION } \\
\hline No. & Remarks & Yogyakarta & Pekalongan & Solo \\
\hline \multirow[t]{7}{*}{3} & Product Marketing & & & \\
\hline & a. Sold on-site (\%) & 26 & 57 & 23 \\
\hline & b. Sold out to big traders (\%) & 10 & 11 & 44 \\
\hline & c. Sold out to retailers (\%) & 14 & 15 & 13 \\
\hline & d. Consignation to retailers $(\%)$ & 0 & 0 & 0 \\
\hline & e. Exported (\%) & 10 & 13 & 7 \\
\hline & f. Production by order only (\%) & 40 & 4 & 13 \\
\hline \multirow[t]{5}{*}{4} & Marketing Scope & & & \\
\hline & a. Out of town $(\%)$ & 57 & 87 & 72 \\
\hline & b. In town $(\%)$ & 32 & 9 & 16 \\
\hline & c. National (\%) & 9 & 2 & 6 \\
\hline & d. Overseas (\%) & 2 & 2 & 6 \\
\hline
\end{tabular}

Source: Data Processed, 2019

\subsubsection{Promotion of Fashion and convection SMIs Products in Yogyakarta, Solo, and Pekalongan City}

Regarding fashion and convection SMIs in Yogyakarta City, 49 percent of fashion and convection entrepreneurs in Yogyakarta City did promotions, while the remaining 51 percent did not do promotions. To note, the amount of fashion and convection SMIs in Yogyakarta City that do and do not do promotion is almost the 
same. 53 percent of fashion and convection entrepreneurs in Solo City did promotions, while the remaining 47 percent did not do promotions. To note, the amount of fashion and convection SMIs in the city of Solo that do and do not do the promotion is almost the same. 20 percent of Fashion and convection SMIs entrepreneurs in Pekalongan Regency do promotions, while the remaining 80 percent do not do promotions. Thus, it can be concluded that the majority of fashion and convection SMI entrepreneurs in Pekalongan Regency do not carry out promotions. This is because the fashion and convection SMIs of Pekalongan Regency already have customers whose number of requests has been very large, so entrepreneurs in Pekalongan Regency feel no need to carry out marketing activities.

If a comparison is made related to the promotion of Fashion and convection SMIs in Yogyakarta, Solo, and Pekalongan, it will be seen that Yogyakarta City and Solo City are equally balanced between fashion and convection SMI entrepreneurs who do and do not carry out promotional activities. This is because some entrepreneurs in both regions still rely on promotional activities to enhance brand image and attract buyers. Some promotional activities can be through exhibitions, online media, and others. This is in contrast to the fashion and convection SMIs of Pekalongan Regency, the majority of which do not carry out promotional activities. This is because the number of customers and the demand from the fashion and convection SMIs in Pekalongan Regency is already very high, so it is felt that there is no need to carry out promotional activities. Even some fashion and convection SMIs in Pekalongan Regency have overloaded demand so that they do not have enough time to do promotional activities.

48 percent of Yogyakarta's fashion and convection SMIs has a promotion strategy to maximize sales, while 32 percent comes is to increase promotions to improve brand image, other methods by 4 percent, and the remaining 8 percent each is by minimizing costs (savings) or is already sufficient because demand is large enough without promotion. Thus, it can be concluded that Yogyakarta's fashion and convection SMIs rely on promotional activities to increase sales and brand image.

As much as 55 percent of the promotion strategies in the Fashion and convection SMIs in Solo City are derived from others (not doing promotion), while the remaining 35 percent come from as much promotion as possible to increase sales, 4 percent decided to stay with current strategy because demand is 
already large enough without promotion, and 3 percent doing minimum promotion as possible to save costs and continue to increase promotions to improve brand image in the city of Solo. Thus, it can be concluded that most of the fashion and convection SMIs entrepreneurs in Solo City do not do promotions and some others maximize promotions to increase sales and brand image.

As much as 78 percent of the promotion strategy used by fashion and convection SMIs in Pekalongan Regency deems their current promotional activities sufficient because demand is large enough without promotion promotion strategies, while the remaining 18 percent is maximizing promotional activities to increase sales, and 4 percent by continuing to carry out activities promotion to enhance brand image. Thus, it can be concluded that, fashion and convection SMIs do not rely on promotion as a means to increase sales or brand image. The number of requests and customers of Fashion and convection SMIs in Pekalongan Regency is already large enough so that promotion is only done in moderation.

If a comparison is made regarding the promotion strategies carried out by fashion and convection SMIs of Yogyakarta, Solo, and Pekalongan, a conclusion will be drawn that Yogyakarta City and Solo City in particular still rely on promotional activities to increase sales and brand image. On the other hand, the fashion and convection SMIs in Pekalongan Regency only carry out sufficient promotional activities because the number of requests is large enough without any promotional activities.

Table 10 Promotion of Fashion and convection SMIs Products in Yogyakarta, Solo, and Pekalongan City

\begin{tabular}{|c|c|c|c|c|}
\hline \multicolumn{5}{|c|}{ PRODUCT CONDITION } \\
\hline No. & Remarks & Yogyakarta & Pekalongan & Solo \\
\hline \multirow[t]{3}{*}{5} & Promotion & & & \\
\hline & a. Yes $(\%)$ & 49 & 20 & 47 \\
\hline & b. No $(\%)$ & 51 & 80 & 53 \\
\hline \multirow[t]{6}{*}{6} & Promotion Strategy & & & \\
\hline & a. Maximum effort to maximize sales (\%) & 48 & 18 & 35 \\
\hline & $\begin{array}{l}\text { b. Adequate due to sufficient demand without } \\
\text { promotion }(\%)\end{array}$ & 8 & 78 & 4 \\
\hline & c. Constant promotion to improve brad image (\%) & 32 & 4 & 3 \\
\hline & d. Minimum effort to reduce costs (\%) & 8 & 0 & 3 \\
\hline & e. Others $(\%)$ & 4 & 0 & 55 \\
\hline
\end{tabular}

Source: Data Processed, 2019 
4.3.5 Government support for Fashion and convection SMIs in the cities of Yogyakarta, Solo, and Pekalongan

Regarding government support for fashion and convection SMIs in the city of Yogyakarta, 70 percent do not feel supported by the government for the development of fashion and convection SMIs, while the remaining 30 percent feel they can get government support for development. In Solo, 60 percent of fashion and convection SMIs do not feel supported by the government for the development of SMIs and convection, while the remaining 40 percent feel they can get government support for development. Regarding government support for fashion and convection SMIs in Pekalongan Regency, 91 percent do not feel they can get government support for the development of SMI and convection, while the remaining 9 percent feel they can get government support for development.

If a comparison is made related to government support for fashion and convection SMIs in the cities of Yogyakarta, Solo, and Pekalongan, there will be similarities between the three, which are equally not getting support from the government in efforts to develop fashion and convection SMIs.

Table 11 Government Support for Fashion and Convection SMIs in the Cities of Yogyakarta, Solo, and Pekalongan

\begin{tabular}{ccccc}
\hline \multicolumn{5}{c}{ PRODUCT CONDITION } \\
\hline No. & Remarks & Yogyakarta & Pekalongan & Solo \\
\hline 8 & Government Support for Development & & & \\
\hline \multicolumn{2}{c}{ a. Yes (\%) } & 30 & 9 & 40 \\
\hline & b. No (\%) & 70 & 91 & 60 \\
\hline
\end{tabular}

Source: Data Processed, 2019

\section{CONCLUSION}

Based on the results of research conducted, conclusions that can be drawn from this study include:

1. SMIs in Yogyakarta, Solo, and Pekalongan still relies from suppliers of raw materials within the city. Fashion and convection SMIs in Yogyakarta, Solo, and Pekalongan still rely on workers from within the city. Especially for 
Pekalongan, 98 percent of the workforce comes from within the city. Sources of capital for fashion and convection SMIs in Yogyakarta, Solo, and Pekalongan mostly come from owners' own capital. Knowledge of the fashion production process of fashion and convection SMIs in Yogyakarta and Pekalongan is mostly from self-taught knowledge while for Solo it is obtained from ancestral heritage. The origin of the technology used in the production process of fashion and convection SMIs for Yogyakarta, Solo, and Pekalongan is dominated by self-purchase of the companies. Fashion and convection SMIs business locations for Yogyakarta and Solo are mostly in the city while for Pekalongan all businesses are in the suburban area.

2. The products produced by Fashion and convection SMIs in Yogyakarta have many product variants while in Solo and Pekalongan the most are standard products that are mass produced. Fashion and convection SMIs pricing strategies for Yogyakarta are using relatively high prices, which is in contrast to Solo and Pekalongan where products are relatively cheap and prices are in line with the market. The marketing of Fashion and convection SMIs products for Yogyakarta is mostly produced in response to orders, while in Pekalongan more are sold locally, and for Solo the most are sold off to large traders. Efforts to promote fashion and convection SMIs in Yogyakarta and Solo are more intensive than Pekalongan. Promotion strategies carried out by fashion and convection SMIs for Yogyakarta and Solo are as much as possible to increase sales, while for Pekalongan is done only sufficiently because demand is large enough without promotion. The marketing scope of fashion and convection SMIs products for Yogyakarta, Solo, and Pekalongan is mostly outside the city. The city of Yogyakarta has the advantage of higher national marketing scope compared to Solo and Pekalongan. Government support for the development of fashion and convection SMIs for Yogyakarta is still higher than Solo and Pekalongan. Fashion and convection SMIs for Pekalongan do not receive development support from the government. The existing support is specific and sparsely distributed. 


\section{REFERENCES}

Alhusain, Achmad Sani. 2015. Kendala dan Upaya Pengembangan Industri Batik di Surakarta Menuju Standardisasi. Jurnal Ekonomi dan Kebijakan Publik, Vol. 6, No. 2, Desember 2015, hal. 199-213.

Basri, Faisal. 2002. Perekonomian Indonesia: Tantangan dan Harapan bagi Kebangkitan Ekonomi Indonesia. Jakarta: Penerbit Erlangga.

Doellah, Santosa. 2002. Batik, Pengaruh Zaman dan Lingkungan. Surakarta: Danar Hadi.

Erma, Setiawati dkk 2015. Pengembangan Komoditas Batik: Determinasi Budaya Ekonomi dan Perubahan Struktur Kebijakan terhadap Perkembangan Usaha Ekonomi Lokal (Studi tentang Pengusaha Batik Laweyan Surakarta). Jurnal Ekonomi dan Bisnis, Vol. XVIII, No. 1, April 2015, hal. 119-134.

Hasibuan, Nurmansyah. 1993. Ekonomi Industri: Persaingan, Monopoli, dan Regulasi. Jakarta: LP3ES.

Indrojarwo, Baroto Tavip. 2010. Development of Indonesia New Batik Design by Exploration and Exploitation of Recent Context. Surabaya: ITS.

Iskandar dan Eny Kustiyah. 2017. Batik sebagai Identitas Kultural Bangsa Indonesia di Era Globalisasi. GEMA, Tahun XXX/52/Agustus 2016-Januari 2017.

Jaya, Wihana K. 2001. Ekonomi Industri Edisi 2. Yogyakarta: Badan Penerbit Fakultas Ekonomi Universitas Gajah Mada.

Kuncoro, Mudrajat. 2007. Ekonomika Industri Indonesia: Menuju Negara Industri Baru 2020. Yogyakarta: Andi Offset.

Lipczynski, John, John Wilson and John Goddard. 2005. Industrial Organization: Competition, Strategy, and Policy. Second Edition. Pearson Education. FT Prentice Hall.

Lipsey, R.G., et al. 1996. Pengantar Mikroekonomi Jilid 2. Edisi Ke-10. Maulana dan Saputra [penerjemah]. Jakarta: Binarupa Aksara.

Martin, S. 1994. Industrial Economics: Economic Analysis and Public Policy. New York: Macmillan Publishing Company.

Mudrajad Kuncoro, P. 2009. Ekonomika Indonesia: Dinamika Lingkungan Bisnis di Tengah Krisis Global. Yogyakarta: UPP STIM YKPN. 
Mansyur. 2000. Industri Kecil, Pemerataan dan Pengembangan Ekonomi Kerakyatan, dalam Indonesia Menapak Abad 21. Kajian Ekonomi Politik, Hlm. 172-195. Jakarta: Dyatama Milenia.

Nurainun, Heriyana dan Rsyimah. 2008. Analisis Industri Batik di Indonesia. Jurnal Fokus Ekonomi (FE), Desember 2008, Vol. 7, No. 3, hal. 124-135. Pramodhawardani, Jaleswari dan Rucianawati. 2001. Usaha Batik Pekalongan pada Masa Krisis.

Purba, Susanti Lasmaria dan P. Eko Prasetyo. 2018. Analisis Faktor Produkis terhadap Daya Saing Batik Semarangan. Economics Development Analysis Journal, 7 (3).

Sumintarsih. 2009. Pelestarian Batik dan Ekonomi Kreatif. Jurnal Penelitian Jantra, Vol. IV, No. 8, Hal. 689-696.

Tambunan, Tulus T. H. 2005. Industrialisasi di Negara Sedang Berkembang. Jakarta: Ghalia Indonesia.

Teguh, Muhammad. 2010. Ekonomi Industri. Jakarta: PT RajaGrafindo Persada. 
Review of Management and Entrepreneurship

Volume 04, Number 01, April 2020 